\title{
Survivorship Issues in Adult Patients With Histiocytic Neoplasms
}

\author{
Kevin O'Brien, RN, MS-CRNP1; Rahul Dave, MD, PhD ${ }^{2, *} ;$ Skand Shekhar, $\mathrm{MD}^{3,4, *}$; Fady Hannah-Shmouni, MD, FRCPC $4,^{*}$;

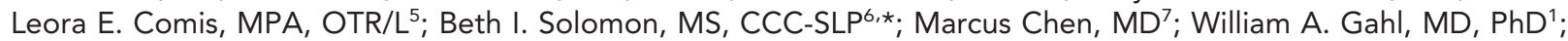 \\ Edmond FitzGibbon, MD'; Bernadette R. Gochuico, MD ${ }^{1}$; and Juvianee I. Estrada-Veras, MD
}

\begin{abstract}
Adult-onset histiocytoses $(\mathrm{AOH})$, primarily Rosai-Dorfman disease (RDD), Erdheim-Chester Disease (ECD), and adult Langerhans cell histiocytosis $(\mathrm{ALCH})$, are a group of related histiocytic neoplastic disorders featuring multisystemic manifestations. The disorders are largely incurable, and are essentially chronic neoplastic diseases with a variable prognosis. Prompt diagnosis and treatment is important to prevent debilitating and even life-threatening complications. Survivorship issues abound in $\mathrm{AOH}$, due to their multisystemic manifestations and the sometimes recalcitrant chronic inflammation, which can lead to other debilitating complications such as fatigue, weakness, and pain. Because these disorders are rare, few healthcare professionals are proficient in their management; therefore the aim of these guidelines is to offer guidance on how to manage patients, and how to create survivorship care plans through the efforts of an interdisciplinary team.
\end{abstract}

J Natl Compr Canc Netw 2021;19(11):1312-1318 doi: 10.6004/jnccn.2021.7096

\footnotetext{
${ }^{1}$ Office of the Clinical Director, National Human Genome Research Institute, $\mathrm{NIH}$, Bethesda, Maryland; ${ }^{2}$ Inova Fairfax-Virginia Commonwealth University College of Medicine, Falls Church, Virginia; ${ }^{3}$ Clinical Research Branch, National Institute of Environmental Health Sciences, NIH, Bethesda, Maryland; ${ }^{4}$ Eunice Kennedy Shriver National Institute of Child Health and Human Development, $\mathrm{NIH}$, Bethesda, Maryland; ${ }^{5}$ Rehabilitation Medicine Department, Clinical Center, $\mathrm{NIH}$, Bethesda, Maryland; ${ }^{6}$ Speech Language Pathology Section, Rehabilitation Medicine Department, Mark O. Hatfield Clinical Research Center, NIH, Bethesda, Maryland; ${ }^{7}$ National Heart, Lung, and Blood Institute, NIH, Bethesda, Maryland; and ${ }^{8}$ National Eye Institute, NIH, Bethesda, Maryland.

*These authors contributed equally to this manuscript.
}

Adult-onset histiocytoses (AOH), primarily Rosai-Dorfman disease (RDD), Erdheim-Chester Disease (ECD), and adult Langerhans cell histiocytosis (ALCH), are rare neoplastic disorders of activated histiocytes, key cells of the innate immune system that, when pathologically activated and proliferating, can create an uncontrolled inflammatory response. Dysregulated inflammation, in conjunction with tumor burden, contributes to endorgan damage, and potentially organ failure. ${ }^{1,2}$ Severity of disease is broad, and some patients are only mildly affected, whereas others have multiple organ systems affected simultaneously, resulting in substantial functional loss and increased morbidity and mortality. ${ }^{1,3,4}$ Moreover, some patients may be mildly affected but unexpectedly develop more serious complications, whereas others who are seriously affected may show dramatic improvement after treatment. This variability in the natural history of disease and response to therapy makes prognostication difficult and underscores the importance of providing diligent care and educating clinicians and patients about the manifestations of these rare disorders.

\section{Survivorship Issues in $\mathrm{AOH}$}

\section{Rarity of the Histiocytoses}

Education is key. Because $\mathrm{AOH}$ are rare, it is likely that patients, family members, and even some medical providers will not be familiar with these disorders and their clinical implications. This is particularly important for medical providers, who are responsible for ordering diagnostic tests, managing symptoms, prescribing treatment, identifying complications, and marshalling resources to meet patients' needs. Incorrect initial diagnoses or prolonged diagnostic evaluations are common and may result in delayed treatment, increasing the risk of poorer outcomes. ${ }^{2,5}$ Patient advocacy organizations such as the Histiocytosis Association, the Histiocyte Society, the Erdheim-Chester Disease Global Alliance, and other similar entities are excellent sources of

See JNCCN.org for supplemental online content. 
education and support for patients, their families, and providers. ${ }^{6}$ Providers knowledgeable about $\mathrm{AOH}$ can schedule time to educate the patient and family and act as a resource for other providers. ${ }^{7,8}$ A proposed list of fundamental educational issues to be discussed with all patients is presented in Table 1.

Neurologic, Musculoskeletal, and Immobility Issues Neurologic complications of $\mathrm{AOH}$ can be devastating and may portend a poor prognosis. ${ }^{1,9}$ Patients may develop multiple neurologic abnormalities because different parts of the central and peripheral nervous system can be simultaneously affected. Simultaneous neurologic deficits create treatment challenges for providers and significant care issues for caregivers. ${ }^{1,2,9}$ The goal of care is to optimize function and allow the patient to safely remain in their residential environment. ${ }^{10}$

\section{Speech and Swallowing Difficulties}

Speech, chewing, and swallowing difficulties may arise from disease in the cerebral cortex, brainstem, cerebellum, or orofacial muscles. ${ }^{1,9}$ Expressive speech difficulties can be frustrating for patients and families. Patients may be unable to express important needs and family members may not understand them or may not know how to remedy the communication issue. Speech therapy can help with exercises, communication strategies, and assistive devices. Next, dysphagia can lead to reduced nutritional intake, and can be a safety issue due to the potential for aspiration of food, saliva, or gastroesophageal refluxate, predisposing to respiratory compromise, pneumonia, and sepsis. ${ }^{11,12}$ A videofluoroscopic swallow study or endoscopy study can determine which phase (eg, oral, pharyngeal, esophageal) of the swallowing process is affected, and can also identify patients who have difficulty protecting

\section{Table 1. Key Educational lssues in $\mathrm{AOH}$}

- With some exceptions, $\mathrm{AOH}$ are considered incurable chronic illnesses that must be managed

- Disease progression may occur, despite treatment; new manifestations or worsening of previously stable disease may require more testing and new treatments

- Treatment is typically long term, and is usually a combination of pharmacologic, physical, and sometimes invasive therapies (eg, indwelling ureteral stents or surgery)

- Some patients may experience a fatal course of the disorder, despite all available treatment, and it is often difficult to predict prognosis upon diagnosis

- $\mathrm{AOH}$ can affect multiple organ systems at different points in the course of the illness, underscoring the importance of regular surveillance and care coordination with various specialists

- Other general health issues should be treated, because the patient's overall health factors into how the disorder can be managed, and into the patient's quality of life

Abbreviation: $\mathrm{AOH}$, adult-onset histiocytoses. their airway. ${ }^{11,12}$ Speech pathologists recommend dietary modifications and teach adaptive maneuvers that minimize aspiration and preserve independence in eating, hopefully reducing the need for gastrostomy tubes. Patients should be screened for warning signs of dysphagia $^{13}$ early in the diagnostic process, and with subsequent disease progression. Lastly, the potential efficacy of medications can be reduced if they cannot be safely swallowed or used as recommended. Notably, some medications for histiocytoses are not FDA-approved to be consumed after being crushed, chewed, or liquified. ${ }^{14-17}$

\section{Balance Issues and Fall Risk}

$\mathrm{AOH}$ can damage various central and peripheral nervous system structures, including motor or sensory cortices, basal ganglia, cerebellum, spinal cord, and peripheral motor and sensory nerves. ${ }^{1,9,18-20}$ Additionally, therapy may also cause central or peripheral neurotoxicity. ${ }^{21}$ These changes, in combination with ostalgia, fatigue, and asthenia, can create balance, gait, and gross and fine motor coordination difficulties. ${ }^{22}$ Deficits can range from mild issues resulting in subtle changes that can be readily addressed with occupational therapy and physical therapy, to profound disability necessitating wheelchairs, personal assistance, home modifications, and even 24-hour care. ${ }^{1}$ These changes also increase the risk of falls, which can have serious consequences ${ }^{23}$ and are predominant in a patient's permanent residence. ${ }^{24} \mathrm{Neu}-$ rologists working with physiatrists and various therapists can assess global functioning, identify deficits, and create a care plan that may include home safety assessments, assistive devices, and rehabilitation. ${ }^{25}$

\section{Self-Care and Dependency Issues}

The loss of motor skills, in conjunction with sensory deficits, ataxia, and poor coordination, create challenges in accomplishing essential health behaviors, such as eating, bathing, dressing, and other self-care activities. ${ }^{26,27}$ The inability to perform such fundamental daily health behaviors can result in skin breakdown, soft tissue infections (eg, oral infections, skin abscesses), dehydration, protein calorie malnutrition, weight loss, and debility. Some patients require assistance with all care needs, without which they could not survive. Providers can partner with caregivers and patients to assess for functional deficits across various environments, including the home, workplace, and local community. Providers can then enlist the help of various therapists to retrain patients, train caregivers, and find effective resources that make activities of daily living safer. Referrals to community agencies or home care rehabilitation services can be provided to help make home modifications for those at risk (Table 2). Lastly, social workers can help obtain home care and transportation services, allowing 
patients to make medical appointments and maintain independence.

\section{Cognitive and Personality Changes}

Cognitive difficulty arises from different pathologic processes. ${ }^{9,28}$ For patients with $\mathrm{AOH}$, various brain lesions and cerebral atrophy, systemic inflammation, endocrine disorders, mood disorders, and medication side effects (eg, interferon-related pseudoatrophy) can cause cognitive decline. ${ }^{1,9}$ Even patients with mild cognitive impairments can experience concentration difficulties or forgetfulness, which may lead to work-related difficulties. More seriously, families may report safety issues such as patients getting lost, leaving on appliances, or financial impulsivity. A careful cognitive evaluation consisting of a detailed history, neurocognitive testing, and perhaps neuropsychologic testing are important steps in the evaluation and treatment of these symptoms. ${ }^{1}$ Organic brain pathology can cause psychiatric symptoms, ${ }^{29}$ such as pseudobulbar affect in patients with ECD. ${ }^{9,30}$ This neurologic complication can be socially disabling and isolating. Notably, education helps patients and their families cope, and dextromethorphan hydrobromide $20 \mathrm{mg}$ /quinidine sulfate $10 \mathrm{mg}$ is an FDA-approved treatment for this condition. ${ }^{31}$

\section{Endocrine Issues}

Endocrine dysfunction is a frequent and early occurrence in $\mathrm{AOH}$, which can be disabling and may be lifelong. ${ }^{32}$ Manifestations can be due to primary organ disease, or secondary to central dysfunction. ${ }^{32,33}$ Moreover, a deficit of $\geq 3$ pituitary hormone axes, termed panhypopituitarism, may occur in some patients with $\mathrm{AOH}$. Early referral to an endocrinologist is warranted. ${ }^{33,34}$ Table 3 details the

\section{Table 2. Clinician Resources for Managing Adult-Onset Histiocytoses}

\begin{tabular}{|c|c|}
\hline Health/Functional Issue & Resources \\
\hline $\begin{array}{l}\text { Provider and patient education about } \\
\text { histiocytoses }\end{array}$ & $\begin{array}{l}\text { Histiocytosis Association (https://histio.org/) } \\
\text { Histiocyte Society (https://www.histiocytesociety.org/) }\end{array}$ \\
\hline $\begin{array}{l}\text { Referral sources for the United States and } \\
\text { Europe }\end{array}$ & $\begin{array}{l}\text { National Organization for Rare Disorders (https://rarediseases.org/) } \\
\text { Memorial Sloan Kettering Cancer Center (https://www.mskcc.org/cancer-care/types/histiocytosis/ } \\
\text { types-histiocytosis) } \\
\text { Texas Children's Hospital (https://www.texaschildrens.org/departments/histiocytosis-program) } \\
\text { European Consortium for Histiocytosis (https://www.echo-histio.net/index_eng.html) } \\
\text { Histio UK (https://www.histiouk.org/) } \\
\text { Erdheim-Chester Disease Global Alliance (https://erdheim-chester.org/) }\end{array}$ \\
\hline General disability resources & $\begin{array}{l}\text { Americans with Disabilities Act (https://www.ada.gov/ada_fed_resources.htm) } \\
\text { USAGov (https://www.usa.gov/disability-services) } \\
\text { National Council on Disability (https://ncd.gov/resources) } \\
\text { HHS.gov (https://www.hhs.gov/programs/social-services/programs-for-people-with-disabilities/index. } \\
\text { html) } \\
\text { American Disability Association (https://www.americandisabilityassociation.org/) } \\
\text { How To Get On (https://howtogeton.wordpress.com/) }\end{array}$ \\
\hline Home modification assistance & $\begin{array}{l}\text { Rebuilding Together (https://rebuildingtogether.org/) } \\
\text { United Disability Services Foundation (https://udservices.org/) } \\
\text { USC Leonard Davis School of Gerontology (https://homemods.org/national-directory/) } \\
\text { HomeAdvisor (https://www.homeadvisor.com/r/grants-for-home-modification/) }\end{array}$ \\
\hline $\begin{array}{l}\text { Resources for the visually impaired } \\
\text { Ocular toxicities }\end{array}$ & $\begin{array}{l}\text { American Council of the Blind (https://www.acb.org/) } \\
\text { National Federation of the Blind (https://nfb.org/resources) } \\
\text { American Foundation for the Blind (https://www.afb.org/blindness-and-low-vision/visionaware) } \\
\text { Hadley (https://hadley.edu/) } \\
\text { World Blind Union (https://worldblindunion.org/) } \\
\text { National Registry of Drug-Induced Ocular Side Effects (http://www.eyedrugregistry.com/) }\end{array}$ \\
\hline Provider and patient endocrine resources & $\begin{array}{l}\text { American Association of Clinical Endocrinologists (https://pro.aace.com/) } \\
\text { Endocrine Society (https://www.endocrine.org/) } \\
\text { National Adrenal Diseases Foundation (https://www.nadf.us/) } \\
\text { American Thyroid Association (thyroid.org/patients) }\end{array}$ \\
\hline Provider and patient neurologic resources & $\begin{array}{l}\text { National Institutes of Neurological Disorders and Stroke (https://www.ninds.nih.gov/disorders/ } \\
\text { support-resources/gov-organizations) } \\
\text { The Association for Neurologically Impaired Brain Injured Children (ANIBIC) (http://www.anibic.org/) }\end{array}$ \\
\hline $\begin{array}{l}\text { Provider and patient kidney disease } \\
\text { resources }\end{array}$ & $\begin{array}{l}\text { National Kidney Foundation (https://www.kidney.org/) } \\
\text { American Kidney Fund (https://www.kidneyfund.org/loved-one-with-kidney-disease.html) } \\
\text { American Association of Kidney Patients (https://aakp.org/) } \\
\text { American Nephrology Nurses Association (https://www.annanurse.org/) }\end{array}$ \\
\hline Provider and patient skin disease resources & $\begin{array}{l}\text { Cancer.net (https://www.cancer.net/) } \\
\text { Oncology Nursing Society (https://www.ons.org/articles/ons-guidelinestm-cancer-treatment-related- } \\
\text { skin-toxicity) }\end{array}$ \\
\hline
\end{tabular}


clinical presentation and management of endocrinopathies in $\mathrm{AOH}$.

Diabetes insipidus is one of the most common endocrinopathies in $\mathrm{AOH}$ and if severe, can result in serious fluid and electrolyte disturbances. ${ }^{1,35-37}$ Its early detection and treatment with desmopressin may decrease the associated morbidity. ${ }^{38}$ Patients and caregivers need education about medication and how to prevent complications such as dehydration.

Hypogonadism can occur in patients of either gender. In men, low levels of testosterone create a variety of symptoms (see Table 3), which can substantially decrease quality of life (QoL). Insufficient testosterone can also cause muscle atrophy and weakness, which can interfere with rehabilitation. Infertility, which is also reported in $\mathrm{AOH}$, is a significant concern for patients planning for families. ${ }^{1,39,40}$

Hypothyroidism is another frequent endocrinopathy in $\mathrm{AOH}$, and its manifestations (see Table 3) can potentially contribute to poor QoL. ${ }^{41}$ Thyroid hormone replacement may help improve QoL and ameliorate symptoms. Providers should be aware that dosage adjustments to maintain a euthyroid state may be necessary during the course of the illness. ${ }^{39-41}$

Adrenal gland dysfunction is common in $\mathrm{AOH}$, and is often bilateral. ${ }^{1,35,42,43}$ Adrenal insufficiency (AI) has an estimated frequency of $35 \%$ in patients with $\mathrm{ECD}$. Central $\mathrm{AI}$ is a potentially devastating endocrinopathy in histiocytosis, and regular screening with prompt treatment may reduce morbidity and mortality. ${ }^{43}$ Patients and caregivers need education about daily replacement therapy, sick-day rules and stress dosing, and how to identify signs and symptoms of an adrenal crisis, which can be life-threatening (see endocrine resources in Table 2). AI symptoms may overlap with other endocrinopathies and other organ complications, which can create challenges in establishing a diagnosis.

Bone and mineral metabolism abnormalities in $\mathrm{AOH}$ can occur due to various osteolytic effects (eg, primary disease effect, uncontrolled endocrinopathies, prolonged immobility, medication side effects). Bone involvement in $\mathrm{AOH}$ can affect many structures of the axial and appendicular skeleton, which may limit function due to ostalgia. ${ }^{1,44}$ Lastly, bone density loss increases fracture risk, which is especially concerning for patients at risk for falls.

\section{Renal and Urologic Issues}

$\mathrm{AOH}$ can have various effects on different parts of the urinary system, ranging from mild asymptomatic renal dysfunction to organ failure. ${ }^{1,30,45-47}$ Because these adverse effects can be insidious and difficult to localize, a systematic approach ensures that all aspects of the urinary system are investigated.

If kidney disease is identified, treatment is directed toward maintaining renal function and preventing further insults. Nephrologists can help manage comorbid medical conditions, coordinate treatment of complications of kidney disease such as proteinuria, and help providers avoid nephrotoxic drugs. Emergent issues such as severe prerenal and postrenal obstruction in ECD may require invasive medical or surgical intervention..$^{1,45,48-50}$ Stenting

\section{Table 3. Endocrine Disorders and Their Management in Patients With Histiocytoses}

\begin{tabular}{|c|c|c|c|c|}
\hline Endocrine Dysfunction & Clinical Manifestations & Evaluation/Workup & Treatment & Referral \\
\hline $\begin{array}{l}\text { Primary and central } \\
\text { hypogonadism }\end{array}$ & $\begin{array}{l}\text { Fatigue, reduced libido, } \\
\text { decreased muscle mass, } \\
\text { erectile dysfunction, } \\
\text { infertility, hot flashes, } \\
\text { sparse facial and body hair, } \\
\text { osteoporosis/fragility } \\
\text { fractures }\end{array}$ & $\begin{array}{l}\text { All patients should have a } \\
\text { baseline assessment of } \\
\text { serum LH, FSH, } 6 \text { a.m. total } \\
\text { testosterone } \times 2 \text { (men), } \\
\text { estradiol (women), semen } \\
\text { analysis (if infertility is a } \\
\text { concern) }\end{array}$ & $\begin{array}{l}\text { Men: replace with oral, } \\
\text { intramuscular, transdermal } \\
\text { or another parenteral } \\
\text { testosterone } \\
\text { Childbearing-age women: } \\
\text { consider hormone } \\
\text { replacement therapy with } \\
\text { transdermal or oral } \\
\text { estrogen formulations }\end{array}$ & $\begin{array}{l}\text { Endocrinologist or a } \\
\text { reproductive specialist }\end{array}$ \\
\hline $\begin{array}{l}\text { Primary and central adrenal } \\
\text { insufficiency }\end{array}$ & $\begin{array}{l}\text { Fatigue, nausea, myalgia, } \\
\text { arthralgia, weakness, } \\
\text { weight loss, abdominal } \\
\text { pain, hypoglycemia }\end{array}$ & $\begin{array}{l}\text { A morning serum cortisol } \\
\text { and ACTH followed by } \\
\text { ACTH stimulation testing }\end{array}$ & $\begin{array}{l}\text { Supplementation with } \\
\text { hydrocortisone at a dose of } \\
10 \text { to } 12 \mathrm{mg} / \text { body surface } \\
\text { area in } 1.73 \mathrm{~m}^{2} \text {; medical } \\
\text { alert bracelet/pocket card; } \\
\text { sick day rules and } \\
\text { hydrocortisone injection } \\
\text { prescription and education }\end{array}$ & Endocrinologist \\
\hline $\begin{array}{l}\text { Primary and central } \\
\text { hypothyroidism }\end{array}$ & $\begin{array}{l}\text { Weight gain, fatigue, } \\
\text { myalgia, cold intolerance, } \\
\text { headache }\end{array}$ & $\begin{array}{l}\text { Baseline evaluation with a } \\
\text { serum TSH, free T4 and T3 }\end{array}$ & $\begin{array}{l}\text { Levothyroxine (conventional } \\
\text { dose for younger adults is } \\
1.6 \mathrm{mcg} / \mathrm{kg} \text { body weight) } \\
\text { with serial monitoring of } \\
\text { free T4 and T3 levels. Goal } \\
\text { of therapy to keep free T4 } \\
\text { in upper half of normal } \\
\text { range }\end{array}$ & $\begin{array}{l}\text { Endocrinologist or a } \\
\text { thyroid disease expert }\end{array}$ \\
\hline
\end{tabular}

Abbreviations: ACTH, adrenocorticotropic hormone; FSH, follicle-stimulating hormone; LH, luteinizing hormone; TSH, thyroid-stimulating hormone. 
of obstructed ureters, the placement of nephrostomy tubes, or use of other urinary drainage systems may preserve renal function. Patients and caregivers require education about the care and risks of these drainage systems. Despite such advanced interventions, some patients progress to end-stage renal disease (ESRD). These patients may require dialysis ${ }^{1}$ and some may be candidates for transplantation..$^{48}$ ESRD creates significant care management issues and is associated with increased morbidity and mortality, which underscores the need to identify renal disease early and institute timely intervention to preserve renal function (see renal resources in Table 2).

\section{Visual Acuity Loss and Other Ocular Issues}

Histiocytic disorders, and their associated therapy, can cause intraocular or extraocular pathology, as well as periorbital pathology, potentially leading to visual loss. ${ }^{1,2,51-54}$ Loss of vision can be insidious or may develop rapidly (eg, drug-induced ocular toxicities). This devastating complication may occur at various points in the illness. ${ }^{2,51}$ In ECD and RDD, histiocytes accumulating in the retro-orbital space may cause proptosis, resulting in corneal damage from prevention of eyelid closure. ${ }^{1,55}$ Unrelieved compression of small-caliber blood vessels, and potentially the optic nerve, may result in ischemic damage. ${ }^{1,51}$ Diplopia may also occur from orbital involvement. Additionally, some medications are associated with rare but serious ocular complications, such as retinal vein occlusion ${ }^{56}$ and retinopathy, whereas radiation treatment for proptosis may result in cataracts and retinopathy. ${ }^{57}$ The National Registry of Drug-Induced Ocular Side Effects is an updated resource to research potential toxicities. ${ }^{58}$ See Table 2 for eye resources.

Visual loss increases the risk of sustaining accidents and impairs functioning. Falls, vehicular and machinery accidents, medication errors due to poor vision, and other risks related to visual impairment can result in permanent injury and further functional loss. Additionally, some patients lose driving privileges, creating transportation problems. To minimize such occurrences, low-vison specialists can assess various aspects of visual functioning and recommend modifications and devices that help maintain independence (see Table 2 for vision resources). For patients with significant visual loss, depression and anxiety are complications that can be addressed through various therapies. ${ }^{59}$ Lastly, preventing visual loss is a priority survivorship issue, necessitating regular eye examinations, the treatment of comorbid illnesses such as diabetes mellitus and hypertension, and managing the ocular effects of aging, all of which help prevent additional loss.

\section{Cardiovascular and Pulmonary Issues}

Cardiac and vascular involvement is described in all $\mathrm{AOH}$ and some may be life-threatening. ${ }^{1,4}$ Almost all structures of the heart can be involved. ${ }^{60,61}$ In ECD, myocardial or pericardial histiocytic infiltration and inflammation can cause tamponade resulting in heart failure ${ }^{62}$ and may require urgent intervention to maintain cardiac output. ${ }^{62,63}$ Histiocytic infiltration of electrical conducting tissue can cause significant arrhythmias and conduction defects, necessitating pharmacotherapy or pacemaker placement. ${ }^{1}$ In ECD, coating of the smaller branches of the aorta may cause stenosis and possibly ischemia. Thus, cardiology consultation is essential for the evaluation and treatment of the various cardiac and vascular manifestations, including drug-induced cardiovascular toxicity. Baseline cardiac studies can be compared with subsequent studies to identify early and important changes. Lastly, some patients with $\mathrm{AOH}$ have an increased frequency of metabolic abnormalities, and these conditions may exacerbate other comorbid medical problems, thereby increasing the risk for cardiovascular disease, which warrants screening and counseling. ${ }^{39}$

$\mathrm{AOH}$ can cause various forms of lung disease. ${ }^{1,44,64,65}$ Histiocytic infiltration of lung tissues can result in intrathoracic lymphadenopathy, pleural effusions, airway disease, or an interstitial lung disease. ${ }^{66}$ Pulmonary involvement can cause debilitating dyspnea, fatigue, and cough. ${ }^{1,44,65}$ These symptoms may be attributed to other problems (eg, cardiac disease), leading to the possibility of lung disease being missed until significant compromise of pulmonary function occurs. Progressive lung disease, sometimes seen in $\mathrm{AOH}$, may require supplemental oxygen and substantial lifestyle modifications, and may be fatal. ${ }^{1,444}$ Pulmonologists can assess respiratory function and initiate pulmonary rehabilitation. Therapists teach energy conservation principles to reduce the work of breathing; techniques for fatigue management; exercises to strengthen accessory respiratory muscles; and adaptive lifestyle changes.

\section{Dermatologic Issues}

The histiocytoses produce a variety of skin lesions that can be difficult to manage and may create social embarrassment. ${ }^{1,4,67,68}$ Patients with ECD may have lesions appearing on many skin surfaces, but characteristically manifest as periorbital xanthelasmas. Medications such as BRAF and MEK inhibitors are associated with an increased risk of skin cancers, as well as other skin lesions, which can occur at various points during therapy ${ }^{69-71}$ Palmar-plantar erythrodysesthesia (hand-foot syndrome) tends to occur during the first few months of therapy, which can be severe if untreated and may result in interruption of therapy. Other agents used as treatments for histiocytoses also have dermatotoxicity, and dermatologists can help manage common adverse events affecting the skin. ${ }^{72}$ Treatment guidelines are available at ASCO.org.

\section{Psychological and Psychosocial Issues}

Despite treatment, some patients are unable to return to premorbid levels of functioning, which can have lifechanging consequences for patients and their families. 
This is especially relevant for disabled long-term survivors, whose care needs may tax family resources. These changes may lead some patients to develop mood disorders and loss of self-esteem or self-worth issues as they confront permanent physical and cognitive limitations. Moreover, job loss may result in lost income and may threaten healthcare access due to loss of medical insurance and other resources, thereby magnifying the stress of adapting to permanent physical changes. This is particularly relevant for $\mathrm{AOH}$ disorders, which often require high-cost care from multiple specialists. Meanwhile, the requirements of everyday life continue despite the patient's illness, leaving others to assume multiple roles, including increasing their work responsibilities to mitigate family income loss to secure medical care and other necessities.

Social interactions, interpersonal bonds, and leisure activities are important stimuli for patients. These connections and activities are fundamental to QoL, especially for those who are physically dependent. Unfortunately, some patients have difficulty maintaining relationships with their spouse, other family members, friends, and colleagues. Such patients may lose meaningful social contacts, leading to depression and hopelessness. These "invisible wounds" can aggravate physical issues such as chronic pain ${ }^{73}$ and may be associated with poor outcomes, especially in older, chronically ill adults. ${ }^{74}$ Referrals to counselors and patient support and advocacy groups can be therapeutic and may generate valuable insights that improve social interactions.

\section{Conclusions}

$\mathrm{AOH}$ are rare and potentially serious disorders that frequently pose difficult diagnostic and management challenges for providers. The multiple and often overlapping manifestations create numerous survivorship issues for patients and caregivers. For some, these disorders can be debilitating, resulting in loss of income, independence, and the ability to perform necessary self-care and other important daily activities. Prognosis varies according to many factors, and care needs for long-term survivors with $\mathrm{AOH}$ may strain family support and other resources. These profound alterations in patients' lives underscore the importance of considering their illness in the context of their life and their available resources. Awareness of these important issues can help providers marshal effective resources to optimize patient health and QoL.

Submitted July 6, 2021; accepted for publication September 22, 2021.

Author contributions: Patient care: O’Brien, Dave, Shekhar, HannahShmouni, Comis, Solomon, Chen, FitzGibbon, Gochuico, Estrada-Veras. Data creation, entry, and analysis: O'Brien, Dave, Shekhar, HannahShmouni, Comis, Solomon, Chen, Gochuico, Estrada-Veras. Manuscript preparation: All authors.

Disclosures: Dr. Dave has disclosed receiving grant/research support and consulting fees from and serving as a scientific advisor for Novartis Pharmaceuticals.

Funding: This work was supported in part by the Intramural Research Programs of the National Human Genome Research Institute; the National Heart, Lung, and Blood Institute; the Rehabilitation Medicine Department at the NIH Clinical Center; the Speech Language Pathology Section of the Rehabilitation Medicine Department at the NIH Clinical Center; Eunice Kennedy Shriver National Institute of Child Health and Human Development; the National Eye Institute, NIH; Clinical Research Branch, National Institute of Environmental Health Sciences, NIH; the National Institute of Neurologic Disorders and Stroke; and the Warren Grant Magnuson Clinical Center, NIH.

Correspondence: Kevin J. O'Brien, RN, MS, CRNP, National Human Genome Research Institute/National Institutes of Health, 10 Center Drive, Building, 10/CRC, Room 3-2551, Bethesda, MD 20892-1205.

Email: obrienke@mail.nih.gov

\section{References}

1. Estrada-Veras JI, O'Brien KJ, Boyd LC, et al. The clinical spectrum of ErdheimChester disease: an obsenvational cohort study. Blood Adv 2017;1:357-366.

2. Goyal G, Young JR, Koster MJ, et al. The Mayo Clinic Histiocytosis Working Group consensus statement for the diagnosis and evaluation of adult patients with histiocytic neoplasms: Erdheim-Chester disease, Langerhans cell histiocytosis, and Rosai-Dorfman disease. Mayo Clin Proc 2019;94:2054-2071.

3. Gul OO, Sisman P, Cander S, et al. An unusual case of adult-onset multisystemic Langerhans cell histiocytosis with perianal and incident thyroid involvement. Endocrinol Diabetes Metab Case Rep 2017;2017:16-0087.

4. Malpas JS. Langerhans cell histiocytosis in adults. Hematol Oncol Clin North Am 1998;12:259-268.

5. Schieppati A, Henter JI, Daina E, et al. Why rare diseases are an important medical and social issue. Lancet 2008;371:2039-2041.

6. Girschikofsky M, Arico M, Castillo D, et al. Management of adult patients with Langerhans cell histiocytosis: recommendations from an expert panel on behalf of Euro-Histio-Net. Orphanet J Rare Dis 2013;8:72.

7. Erdheim-Chester Disease Global Alliance. Care Monitoring. Accessed June 11, 2021. Available at: https://erdheim-chester.org/care-monitoring/

8. National Center for Advancing Translation Sciences: Genetic and Rare Diseases Information Center. Caring for your patient with a rare disease. Accessed June 11, 2021. Available at: https://rarediseases.info.nih.gov/ guides/pages/122/caring-for-your-patient-with-a-rare-disease

9. Boyd LC, O'Brien KJ, Ozkaya N, et al. Neurological manifestations of Erdheim-Chester disease. Ann Clin Transl Neurol 2020;7:497-506.
10. Howard RS. Neurologic care in the home. J Neurol Neurosurg Psychiatry 1997;63(Suppl 1):S61-64.

11. Mandell LA, Niederman MS. Aspiration pneumonia. N Engl J Med 2019; 380:651-663.

12. Shigematsu T, Fujishima I. Dysphagia and swallowing rehabilitation [in Japanese]. Brain Nerve 2015;67:169-182.

13. Malhi H. Dysphagia: warning signs and management. Br J Nurs 2016;25: 546-549.

14. Darrigade Fleury M, Masson Regnault M, Cales S, et al. Alternative use of BRAF inhibitors in patients with metastatic melanoma unable to swallow pills. J Oncol Pharm Pract 2021;27:996-999.

15. Janson B, Whittle J, Witney $K$, et al. Use of vemurafenib in a patient unable to swallow whole. J Oncol Pharm Pract 2016;22:733-737.

16. Arnold-Korzeniowsk K. Trametinib (Mekinist) | OncoLink website. Accessed June 11, 2021. Available at: https://www.oncolink.org/cancertreatment/oncolink-rx/trametinib-mekinist-r

17. Stegemann S, Gosch M, Breitkreutz J. Swallowing dysfunction and dysphagia is an unrecognized challenge for oral drug therapy. Int J Pharm 2012;430:197-206.

18. Duarte-Celada WR, Thakolwiboon S, Brandi L, et al. Adult Langerhans cell histiocytosis of the central nervous system. Proc (Bayl Univ Med Cent) 2020;33:603-605.

19. Sandoval-Sus JD, Sandoval-Leon AC, Chapman JR, et al. Rosai-Dorfman disease of the central nervous system: report of 6 cases and review of the literature. Medicine (Baltimore) 2014;93:165-175. 
20. Le Guennec L, Martin-Duverneuil N, Mokhtari K, et al. Neuro-Langerhans cell histiocytosis [in French]. Presse Med 2017;46:79-84.

21. Magge RS, DeAngelis LM. The double-edged sword: neurotoxicity of chemotherapy. Blood Rev 2015;29:93-100.

22. MacKinnon CD. Sensorimotor anatomy of gait, balance, and falls. Handb Clin Neurol 2018;159:3-26.

23. Centers for Disease Control and Prevention. Important facts about falls. Accessed June 11, 2021. Available at: https://www.cdc.gov/ homeandrecreationalsafety/falls/adultfalls.html

24. Homann B, Plaschg A, Grundner M, et al. The impact of neurological disorders on the risk for falls in the community dwelling elderly: a case-controlled study. BMJ Open 2013;3:e003367.

25. Tyson BT, Pham MT, Brown NT, et al. Patient safety considerations in the rehabilitation of the individual with cognitive impairment. Phys Med Rehabil Clin N Am 2012;23:315-334.

26. Goldenhart LG, Nagy H. Assisting patients with personal hygiene. In: StatPearls [Internet]. Treasure Island, FL: StatPearls Publishing; 2021.

27. Wayne J. The importance of self-care in chronic illness management. Accessed June 11, 2021. Available at: https://thedoctorweighsin.com/chronic-illness-self-care/

28. Garg D, Pedapati R, Nakra T, et al. Langerhans cell histiocytosis presenting as a rapidly evolving frontotemporal syndrome. Neurol Sci 2019;40:1055-1058.

29. King RR, Reiss JP. The epidemiology and pathophysiology of pseudobulbar affect and its association with neurodegeneration. Degener Neurol Neuromuscul Dis 2013;3:23-31.

30. Diamond EL, Dagna L, Hyman DM, et al. Consensus guidelines for the diagnosis and clinical management of Erdheim-Chester disease. Blood 2014; 124:483-492.

31. Ahmed A, Simmons Z. Pseudobulbar affect: prevalence and management. Ther Clin Risk Manag 2013;9:483-489.

32. Goyal G, Heaney ML, Collin M, et al. Erdheim-Chester disease: consensus recommendations for evaluation, diagnosis, and treatment in the molecular era. Blood 2020;135:1929-1945.

33. Shekhar S, Irizarry-Caro JA, Sinaii N, et al. Pituitary imaging abnormalities and related endocrine dysfunctions in Erdheim-Chester disease. Cancers (Basel) 2021;13:4126

34. Fleseriu M, Hashim IA, Karavitaki N, et al. Hormonal replacement in hypopituitarism in adults: an Endocrine Society clinical practice guideline. J Clin Endocrinol Metab 2016;101:3888-3921.

35. Makras P, Alexandraki KI, Chrousos GP, et al. Endocrine manifestations in Langerhans cell histiocytosis. Trends Endocrinol Metab 2007;18:252-257.

36. Kaltsas GA, Powles TB, Evanson J, et al. Hypothalamo-pituitary abnormalities in adult patients with langerhans cell histiocytosis: clinical, endocrinological, and radiological features and response to treatment. J Clin Endocrinol Metab 2000;85:1370-1376.

37. Zhang Y, Liu J, Zhu J, et al. Case report: Rosai-Dorfman disease involving sellar region in a pediatric patient: a case report and systematic review of literature. Case Report. Front Med (Lausanne) 2020;7:613756

38. Oiso Y, Robertson GL, Nørgaard JP, et al. Clinical review: treatment of neurohypophyseal diabetes insipidus. J Clin Endocrinol Metab 2013;98:3958-3967.

39. Courtillot C, Laugier Robiolle S, Cohen Aubart F, et al. Endocrine manifestations in a monocentric cohort of 64 patients with Erdheim-Chester disease. J Clin Endocrinol Metab 2016;101:305-313.

40. Sagna Y, Courtillot C, Drabo JY, et al. Endocrine manifestations in a cohort of 63 adulthood and childhood onset patients with Langerhans cell histiocytosis. Eur J Endocrinol 2019;181:275-285.

41. Shekhar S, Sinaii N, Irizarry-Caro JA, et al. Prevalence of hypothyroidism in patients with Erdheim-Chester disease. JAMA Netw Open 2020;3:e2019169.

42. Papadakis G, Shekhar S, Irizarry-Caro J, et al. Increased metabolic activity of the adrenal glands assessed by 18F-FDG PET/CT in patients with Erdheim-Chester disease associated with the BRAF V600E disease causing variant. J Nucl Med 2021;62(Suppl 1):1112.

43. Hannah-Shmouni F, Boyd L, Papadakis GZ, et al. Association of BRAF V600E with hypothalamic-pituitary-adrenal axis involvement in ErdheimChester disease. Endocr Metab Sci 2020;1:100051.

44. Malpas J, Norton A. Langerhans cell histiocytosis in the adult. Med Pediatr Oncol 1996;27:540-546.

45. Sanchez JE, Mora C, Macia M, et al. Erdheim-Chester disease as cause of end-stage renal failure: a case report and review of the literature. Int Urol Nephrol 2010;42:1107-1112.
46. Anabi A, Tarrass F, Hachim K, et al. Nephrotic syndrome revealing a disseminated Langerhans' cell histiocytosis. J Nephrol 2005;18:777-780.

47. Laboudi A, Haouazine N, Benabdallah L, et al. Rosai-Dorfman disease revealed by renal failure: case report [in French]. Nephrologie 2001;22:53-56.

48. Yoo J, Gunsteen C, Patel S, et al. Kidney transplantation for ErdheimChester disease. Case Rep Transplant 2020;2020:3954165.

49. Sarkis J, Haddad F, Nasr S, et al. Bilateral renal colic as an initial presentation of Erdheim-Chester disease. Case Rep Urol 2019;2019:4670376.

50. Wimpissinger TF, Schernthaner G, Feichtinger $\mathrm{H}$, et al. Compression of kidneys in Erdheim-Chester disease of retroperitoneum: open surgical approach. Urology 2005;65:798.

51. Choi MB, Salomão DR, Smith WM, et al. Ophthalmic findings of RosaiDorfman disease. Am J Ophthalmol 2018;188:164-172.

52. McClellan SF, Ainbinder DJ. Orbital Rosai-Dorfman disease: a literature review. Orbit 2013;32:341-346.

53. Masoomian B, Lally SE, Shields JA, et al. Ophthalmic manifestations of RosaiDorfman disease in five patients. J Curr Ophthalmol 2020;32:238-243.

54. O' Reilly $P$, Patel V, Luthert $P$, et al. Orbital Rosai-Dorfman disease with subperiosteal bone involvement mimicking eosinophilic granuloma. Orbit 2012;31:24-26.

55. Wang E, Anzai Y, Paulino A, et al. Rosai-Dorfman disease presenting with isolated bilateral orbital masses: report of two cases. AJNR Am J Neuroradiol 2001;22:1386-1388.

56. Sarny $S$, Neumayer $M$, Kofler J, et al. Ocular toxicity due to trametinib and dabrafenib. BMC Ophthalmol 2017;17:146

57. Jeganathan VS, Wirth A, MacManus MP. Ocular risks from orbital and periorbital radiation therapy: a critical review. Int J Radiat Oncol Biol Phys 2011;79:650-659

58. National Registry of Drug-Induced Ocular Side Effects. About the registry. Accessed June 25, 2021. Available at: http://www.eyedrugregistry.com/

59. Demmin DL, Silverstein SM. Visual impairment and mental health: unmet needs and treatment options. Clin Ophthalmol 2020;14:4229-4251.

60. Tica I, Seceleanu M, Tica AA, et al. Histiocytosis $X$ and pericarditis - a rare association and a difficult diagnosis. Curr Health Sci J 2016;42:417-421.

61. Ajise OE, Stahl-Herz J, Goozner B, et al. Extranodal Rosai-Dorfman disease arising in the right atrium: a case report with literature review. Int J Surg Pathol 2011;19:637-642.

62. George OK, Subhendu MS. Recurrent and rapidly occurring pericardial tamponade in Erdheim Chester disease. Indian Heart J 2012;64:103-105.

63. Nakhleh A, Slobodin G, Elias N, et al. Rapid progression to cardiac tamponade in Erdheim-Chester disease despite treatment with interferon alpha. Mod Rheumatol 2016;26:621-624.

64. Al Umairi R, Blunt D, Hana W, et al. Rosai-Dorfman disease: rare pulmonary involvement mimicking pulmonary Langerhans cell histiocytosis and review of the literature. Case Rep Radiol 2018;2018:2952084.

65. Cartin-Ceba R, Golbin JM, Yi ES, et al. Intrathoracic manifestations of Rosai-Dorfman disease. Respir Med 2010;104:1344-1349.

66. Haroutunian SG, O'Brien KJ, Estrada-Veras JI, et al. Clinical and histopathologic features of interstitial lung disease in Erdheim-Chester disease. J Clin Med 2018;7:E243.

67. Goyal G, Heaney ML, Collin M, et al. Erdheim-Chester disease: consensus recommendations for evaluation, diagnosis, and treatment in the molecular era. Blood 2020;135:1929-1945.

68. Munn S, Chu AC. Langerhans cell histiocytosis of the skin. Hematol Oncol Clin North Am 1998;12:269-286.

69. Carlos G, Anforth R, Clements A, et al. Cutaneous toxic effects of BRAF inhibitors alone and in combination with MEK inhibitors for metastatic melanoma. JAMA Dermatol 2015;151:1103-1109.

70. Welsh SJ, Corrie PG. Management of BRAF and MEK inhibitor toxicities in patients with metastatic melanoma. Ther Adv Med Oncol 2015;7:122-136.

71. Anforth R, Fernandez-Peñas P, Long GV. Cutaneous toxicities of RAF inhibitors. Lancet Oncol 2013;14:e11-18.

72. Gnanendran SS, Turner LM, Miller JA, et al. Cutaneous adverse events of antiPD-1 therapy and BRAF inhibitors. Curr Treat Options Oncol 2020;21:29.

73. Ahmad AH, Zakaria R. Pain in times of stress. Malays J Med Sci 2015;22:52-61.

74. Petitte T, Mallow J, Barnes E, et al. A systematic review of loneliness and common chronic physical conditions in adults. Open Psychol J 2015;8 (Suppl 2):113-132. 

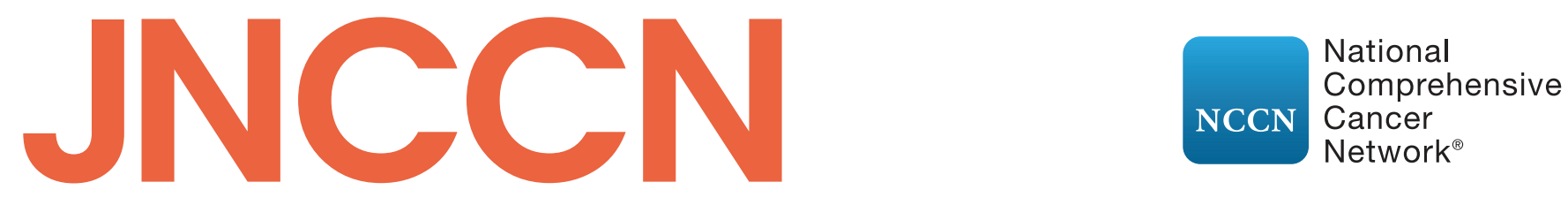

JOURNAL OF THE NATIONAL COMPREHENSIVE CANCER NETWORK

Supplemental online content for:

\section{Survivorship Issues in Adult Patients With Histiocytic Neoplasms}

Kevin O'Brien, RN, MS-CRNP; Rahul Dave, MD, PhD; Skand Shekhar, MD;

Fady Hannah-Shmouni, MD, FRCPC; Leora E. Comis, MPA, OTR/L; Beth I. Solomon, MS, CCC-SLP;

Marcus Chen, MD; William A. Gahl, MD, PhD; Edmond FitzGibbon, MD; Bernadette R. Gochuico, MD; and Juvianee I. Estrada-Veras, MD

J Natl Compr Canc Netw 2021;19(11):1312-1318

eAppendix 1: Oral and Otolaryngological Issues 


\section{eAppendix 1.Oral and Otolaryngological Issues}

Almost all oral and otolaryngological structures can be affected by adult-onset histiocytoses (AOH) ${ }^{1-5}$ Mandibular and maxillary involvement, periodontal disease, all can erode bone, causing pain and tooth loss, ${ }^{1,3}$ which may interfere with chewing, predisposing to dysphagia. ${ }^{5}$ Chronic xerostomia increases the risk of caries, buccal and tongue ulcers, infections (especially candidiasis), tooth and gum loss, dysarthria and dysphagia, and halitosis. ${ }^{6}$ Some medications and treatments can exacerbate xerostomia (eg, anticholinergics, antihistamines, chemotherapeutics, therapeutic radiation), and the regular use of moisturizing agents may help. ${ }^{6}$ Frequent oral care (every 3 to 6 months) with careful surveillance of tooth and bone integrity (especially alveolar bone), salivary structures, and inspection for aphthae and signs of infection is warranted.

The 4 sinus cavities and their surrounding bony structures, the facial bones and mandible, and the calvarium and skull base can all be sites of histiocytic disease activity. ${ }^{4,5-9}$ Untreated proliferative disease with attendant inflammation can cause erosion into the orbit, ear canal, or middle ear compartment, endangering visual or otologic structures. ${ }^{10,11}$ Patients with infiltrative disease activity into, or originating from, these bony compartments may present with nondescript or common symptoms, such as ear/eye pain, signs of otitis externa/media, otorrhea, sinusitis, periorbital or periauricular swelling, or visual changes. ${ }^{7,9,11-13}$ The underlying etiology for these symptoms may not be immediately obvious given that histiocytic (ie, neoplastic ) disease activity deep in the skull and facial bones may not be readily apparent on an external examination using only routine office equipment ${ }^{9,12,14}$; therefore, the appearance of such symptoms in a patient with known or suspected histiocytosis should prompt consultation with an evaluation for both common causes, and for histiocytic disease activity to prevent serious complications (ie, permanent visual and hearing/vestibular function loss). ${ }^{4,9}$ The possibility of such complications underscores the importance of regular surveillance examsinations by care team members.

\footnotetext{
References

1. Artzi Z, Gorsky M, Raviv M. Periodontal manifestations of adult onset of histiocytosis X. J Periodontol 1989;60:57-66.

2. Cranin AN, Rockman R. Oral symptoms in histiocytosis X. J Am Dent Assoc 1981;103:412-416.

3. Sorenson AD, Emam HA. Oral findings of Erdheim-Chester disease: a case report and review of the literature. J Oral Maxillofac Surg 2021;79:1287-1291.

4. Diamond EL, Dagna L, Hyman DM, et al. Consensus guidelines for the diagnosis and clinical management of Erdheim-Chester disease. Blood 2014;124:483-492.

5. Estrada-Veras JI, O'Brien KJ, Boyd LC, et al. The clinical spectrum of Erdheim-Chester disease: an observational cohort study. Blood Adv 2017;1:357-366.

6. Artzi Z, Grosky M, Raviv M, et al. Periodontal manifestations of adult onset of histiocytosis X. J Periodontol 1989;60:57-66.

7. Bartels CL. Xerostomia. The Oral Cancer Foundation website Accessed October 8, 2021.https://oralcancerfoundation.org/complications/xerostomia/

8. Kleinjung T, Woenckhaus M, Bachthaler M, et al. Langerhans' cell histiocytosis with bilateral temporal bone involvement Am J Otolaryngol 2003:24:265-270.

9. Bastianpillai J, Haloob N, Panchappa SA, Marais J. The rare case of an adult-onset xanthogranuloma of the paranasal sinuses: a histological dilemma Case Rep Pathol 2020;2020:2847821.

10. Marinelli JP, Peters PA, Vaglio A, et al. Skull base manifestations of Erdheim-Chester disease: a case series and systematic review. Neurosurgery 2019;85:E693-701.

11. AlKuwaity KW, Alosaimi MH, Alsahlawi KT, et al. Unusual presentation of Rosai-Dorfman disease: report of a rare case. Am J Case Rep 2019;20:91-96.

12. Gungadeen A, Kullar P, Yates P, et al. Otic Langerhans' cell histiocytosis in an adult: a case report and review of the literature. Case Rep Otolaryngol 2013:2013:259726.

13. Cuoco JA, Guilliams EL, Klein BJ, et al. Atypical presentation of Langerhans cell histiocytosis of the skull. JAMA Otolaryngol Head Neck Surg 2020; 146:975-977.

14. Devaney KO, Putzi MJ, Ferlito A, et al. Head and neck Langerhans cell histiocytosis. Ann Otol Rhinol Laryngol 1997;106:526-532.

15. Thust SC, Yousry T. Imaging of skull base tumours. Rep Pract Oncol Radiother 2016;21:304-318.
} 